\title{
Increasing meltwater discharge from the Nuuk region of the Greenland ice sheet and implications for mass balance (1960-2012)
}

\section{Dirk VAN AS, ${ }^{1}$ Morten Langer ANDERSEN, ${ }^{1}$ Dorthe PETERSEN, ${ }^{2}$ Xavier FETTWEIS, ${ }^{3}$ Jan H. VAN ANGELEN,${ }^{4}$ Jan T.M. LENAERTS, ${ }^{4}$ Michiel R. VAN DEN BROEKE, ${ }^{4}$ James M. LEA, ${ }^{5}$ Carl E. BØGGILD, ${ }^{6}$ Andreas P. AHLSTR $\varnothing M^{1}{ }^{1}$ Konrad STEFFEN $^{7}$}

\author{
${ }^{1}$ Geological Survey of Denmark and Greenland (GEUS), Copenhagen, Denmark \\ E-mail:dva@geus.dk \\ ${ }^{2}$ Greenland Survey (Asiaq), Nuuk, Greenland \\ ${ }^{3}$ Department of Geography, University of Liège, Liège, Belgium \\ ${ }^{4}$ Institute for Marine and Atmospheric Research Utrecht, Utrecht University, Utrecht, The Netherlands \\ ${ }^{5}$ Cryosphere \& Climate Change, School of Geosciences, University of Aberdeen, Aberdeen, UK \\ ${ }^{6}$ Technical University of Denmark, Kongens Lyngby, Denmark \\ ${ }^{7}$ Swiss Federal Institute for Forest, Snow and Landscape Research (WSL), Birmensdorf, Switzerland
}

\begin{abstract}
We assess the runoff and surface mass balance (SMB) of the Greenland ice sheet in the Nuuk region (southwest) using output of two regional climate models (RCMs) evaluated by observations. The region encompasses six glaciers that drain into Godthåbsfjord. RCM data (1960-2012) are resampled to a high spatial resolution to include the narrow (relative to the native grid spacing) glacier trunks in the ice mask. Comparing RCM gridded results with automatic weather station (AWS) point measurements reveals that locally models can underestimate ablation and overestimate accumulation by up to tens of per cent. However, comparison with lake discharge indicates that modelled regional runoff totals are more accurate. Model results show that melt and runoff in the Nuuk region have doubled over the past two decades. Regional SMB attained negative values in recent high-melt years. Taking into account frontal ablation of the marine-terminating glaciers, the region lost $10-20 \mathrm{~km}^{3}$ w.e. $\mathrm{a}^{-1}$ in $2010-12$. If 2010 melting prevails during the remainder of this century, a low-end estimate of sea-level rise of $5 \mathbf{m m}$ is expected by 2100 from this relatively small section $(2.6 \%)$ of the ice sheet alone.
\end{abstract}

KEYWORDS: glacier meteorology, ice-sheet mass balance, ice/atmosphere interactions, surface melt

\section{INTRODUCTION}

The Greenland ice sheet has been losing mass at an accelerating pace over the past two decades (Rignot and others, 2011). A mass balance of $-234 \pm 20 \mathrm{Gta}^{-1}$ (April 2002 to February 2012) was derived from Gravity Recovery and Climate Experiment (GRACE) data (Barletta and others, 2013). At least half of this mass loss is attributed to a reduction in the surface mass balance (SMB) (Van den Broeke and others, 2009). This is in part due to an increase in melt area (Fettweis and others, 2011). During warm summer periods, such as July 2012, surface melt can occur across almost the entire ice sheet (Nghiem and others, 2012). Melt has increased due to the long-known atmospheric warming in Greenland (Box, 2002) and in recent years has been amplified by atmospheric and oceanic conditions favouring high pressure over Greenland, such as a negative North Atlantic Oscillation (NAO) index (Fettweis and others, 2013; Hanna and others, 2013). Owing to the increased melt, the ice sheet's surface albedo is declining (Box and others, 2012), resulting in larger solar radiation absorption and thus stronger melt (melt-albedo feedback).

When investigating the causes of mass loss from the Greenland ice sheet, it is important to distinguish between regions, as atmospheric and oceanic impacts on ice dynamics and SMB are spatially highly variable. For instance, compared with the east coast, the west of the ice sheet has exhibited strong warming associated with changes in the summer general circulation (Fettweis and others, 2013) and causing mass loss in recent years (Sasgen and others, 2012). In this study we focus on the Godthåbsfjord/ Nuuk region in southwest Greenland (Fig. 1). This area has undergone intermittent but substantial glacier shrinkage since the 18th century; Kangiata Nunaata Sermia (KNS) has retreated $>20 \mathrm{~km}$ since the Little Ice Age (Weidick and others, 2012). Glacier mass loss yields increased freshwater inflow into the fjord by enhanced runoff and/or calving. Mortensen and others (2013) showed that the glacial meltwater greatly impacts the fjord's salinity and circulation, which in turn controls frontal ablation of marine-terminating glaciers.

Our aim is to assess and explain the changes in SMB of the glacial catchments in the Nuuk region over recent decades. This provides us with freshwater runoff estimates, which are vital to studies of fjord circulation, given that annual glacier runoff equals roughly one-tenth of the water in the entire inner fjord. Automatic weather station (AWS) data can be used to explicitly resolve the surface energy and mass balance of ice sheets (Andersen and others, 2010; Van den Broeke and others, 2011; Van As and others, 2012). However, there is a limit to spatial extrapolation of meteorological observations, as correlation is lost with increasing distance (Box, 2002). In this study we therefore rely on two regional climate models (RCMs): the Modèle Atmosphérique Régional (MAR, version 3.2) and the Regional Atmospheric 


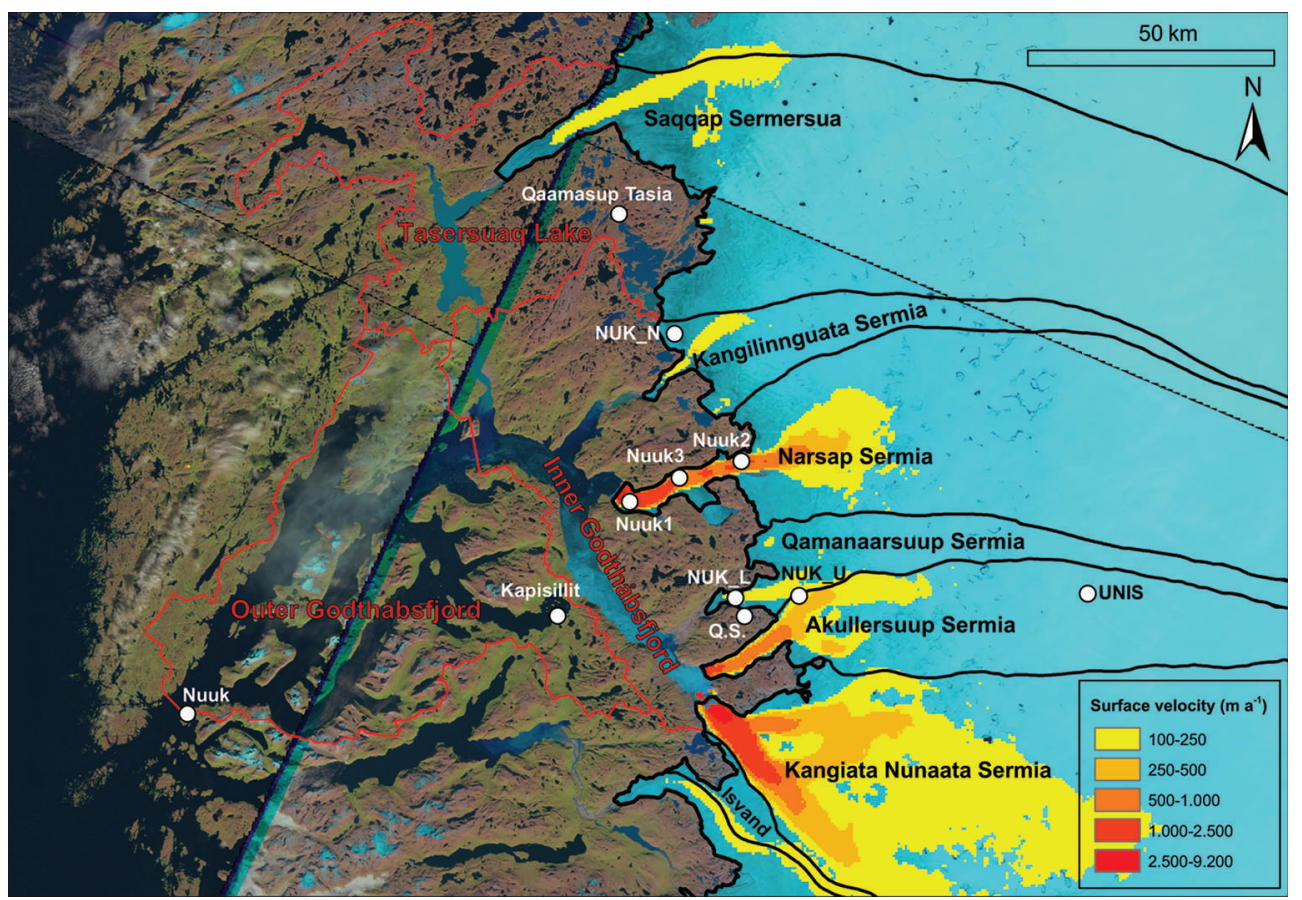

Fig. 1. Drainage basins and surface velocities in the Nuuk region of Greenland overlain on Landsat imagery from 1999-2002 and RADARSAT-derived surface velocities for winter 2005/06. Dots indicate weather station locations.

Climate Model (RACMO2). These RCMs have proven to be valuable tools for estimating Greenland ice sheet SMB (Ettema and others, 2009; Fettweis and others, 2011).

To be able to obtain meltwater runoff and SMB estimates for the Nuuk region, we first delineate catchments. RCM output is resampled to a fine grid spacing so that the modelled ice masks closely match the actual ice-covered area in this region, with outlet glaciers that are narrow compared with the native grid spacings of the RCMs. We evaluate model performance with AWS observations and discharge measurements from a proglacial lake that collects meltwater from the ice sheet.

\section{METHODS}

\subsection{Area of interest and catchment delineation}

The Godthåbsfjord/Nuuk region of Greenland $\left(63-66^{\circ} \mathrm{N}\right.$, $44-53^{\circ} \mathrm{W}$ ) (Fig. 1) is a mountainous fjord system that borders a section of the ice sheet spanning $\sim 46200 \mathrm{~km}^{2}$, $2.6 \%$ of the Greenland ice sheet area. The marginal region of the ice sheet consists of six outlet glaciers named:

Saqqap Sermersua (SS), land-terminating

Kangilinnguata Sermia (KS), land-terminating

Narsap Sermia (NS), marine-terminating

Qamanaarsuup Sermia (QS), land-terminating

Akullersuup Sermia (AS), marine-terminating

Kangiata Nunaata Sermia (KNS), marine-terminating

The meltwater from SS first collects in Tasersuaq Lake (TL; Fig. 1). The ice-dammed Isvand Lake (IL) currently drains underneath KNS into Godthåbsfjord. Until 2004 its water level was high enough to overspill into Austmannadalen, a valley that has no direct hydrological connection to Godthåbsfjord (Weidick and Citterio, 2011).
By delineating the hydrological drainage basins we can determine the freshwater fluxes at the multiple entry points to the inner Godthåbsfjord (GFI), and thus the total flux into the outer fjord (GFO). This is done using the Advanced Spaceborne Thermal Emission and Reflection Radiometer (ASTER) digital elevation model (DEM) (Hvidegaard and others, 2012) and aerial photography. Over the ice sheet, a topographical delineation may lead to large errors in the catchment delineation at high elevation, partly because standard hydrological tools in software packages such as ArcGIS are inaccurate over large smooth surfaces (Van As and others, 2012). Furthermore, in southwest Greenland, surface meltwater does not run off along the ice-sheet surface. Before reaching the margin, the meltwater flows into moulins and crevasses that conduct it to the glacier bed. This implies an influence of subglacial topography. Since a sufficiently accurate bedrock map does not exist, we delineate the glacier catchment from the 2005/06 RADARSAT surface velocity map (Joughin and others, 2010) using the ArcGIS particle track function. We implicitly assume that the direction of ice flow is a function of both surface and bottom topography. With this method the glaciers are delineated dynamically as well as hydrologically, allowing us to study their mass budgets and freshwater contributions to the fjord.

\subsection{RCMs and resampling}

To determine the SMB components for the study region we use output of the two meteorological models MARv3.2 and RACMO2. Both RCMs include a surface layer of snow and ice two-way coupled to the atmosphere to allow for realistic calculation of the surface energy and mass fluxes at the iceatmosphere interface. This makes it possible to estimate meltwater refreezing in the snowpack (Reijmer and others, 2012) and subsurface heat and mass fluxes on a multilevel grid. Also, the models calculate albedo change due to snow metamorphosis and bare-ice appearance (Rae and others, 2012), a first-order feedback on surface melt (Box and others, 


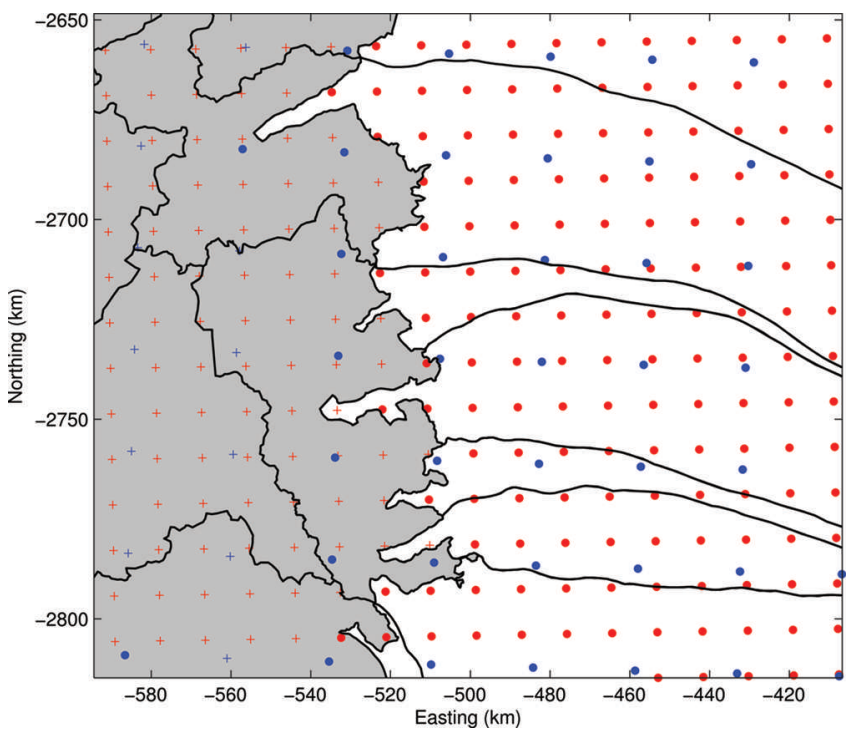

Fig. 2. Catchments from Figure 1 (black lines) overlain by RCM grids. MARv3.2 (blue) grid spacing is $25 \mathrm{~km}$, and RACMO2 (red) grid spacing is $11 \mathrm{~km}$. Dots represent partial or full ice cover in the model masks; crosses (+) represent tundra and fjord.

2012). Minimum values are set to 0.4 for MARv3.2 and to a remotely sensed minimum albedo field for RACMO2 (Van Angelen and others, 2012). Both RCMs are forced at the boundaries by European Centre for Medium-Range Weather Forecasts (ECMWF) reanalysis data (Dee and others, 2011). The longest period for which both models have results is 1960-2012, defining our study period. For details on MARv2 and RACMO2 physics we refer to Fettweis and others (2011) and Van Angelen and others (2012), respectively. The former is upgraded to MARv3.2 with a new ice-sheet topography and mask, in addition to improvements in cloud microphysics reducing precipitation. MARv3.2 is run at $25 \mathrm{~km}$ and RACMO2 at $11 \mathrm{~km}$ horizontal grid resolution.

We do not make use of the models' ice mask fractional cover along the ice-sheet margin in order to eliminate this potential cause of model disagreement, but use the outlines as determined from recent Landsat imagery. However, the RCM grids do not resolve the $1.5-5.0 \mathrm{~km}$ wide outlet glaciers in the Nuuk sector of the Greenland ice sheet (Fig. 2), while the SMB components such as melt on the unresolved glacier areas likely are substantial. We address this by means of bilinear interpolation to a finer grid, chosen to have a $250 \mathrm{~m}$ resolution that fully resolves the narrowest glacier in the region. For this resampling, only same-surfacetype gridpoints were used, i.e. the values at resampled ice surface points are determined using on-ice values only and not tundra values.

\subsection{Model evaluation by observations}

Meteorological measurements in Nuuk date back to the 18th century (Vinther and others, 2006). In recent decades more weather records on land have been obtained by the Danish Meteorological Institute (DMI), Asiaq (Greenland Survey) and the Greenland Airports (GL). The 13 weather stations selected for this study are positioned within the catchments mentioned above (Table 1). On the ice sheet, the first continuous and still ongoing measurements within the hydrological catchment of Godthåbsfjord were performed as part of the Greenland Climate Network (GC-Net) (Steffen and others, 1996) in 1997. Several more stations have been erected since, among which three are in the ablation zone for the Programme for Monitoring the Greenland Ice Sheet (PROMICE) (Van As and others, 2013). Here we summarize a detailed RCM evaluation using AWS observations. Modelled SMB is evaluated in Section 3.

Variability of daily mean near-surface air temperature is captured well by the models, with correlation coefficients $(r)$ exceeding 0.95 at all stations except one. Root-mean-square errors (RMSEs) range from $2^{\circ} \mathrm{C}$ to $8^{\circ} \mathrm{C}$, partly explicable by differences in actual and model site elevations. Correlation coefficients for air pressure are high (0.97-0.99). For wind speed, correlation coefficients are lower, down to 0.6, with mean errors in the order of $1 \mathrm{~m} \mathrm{~s}^{-1}$. Downward shortwave radiation is relatively accurate, with no clear offset and

Table 1. Metadata for selected automated weather observations within the study region and period. Weather stations below the dividing line were/are positioned on the ice sheet

\begin{tabular}{lllll}
\hline Name/location & Latitude $(\mathrm{N})$ & Longitude $(\mathrm{W})$ & Elevation & Operator
\end{tabular}

$\mathrm{m}$

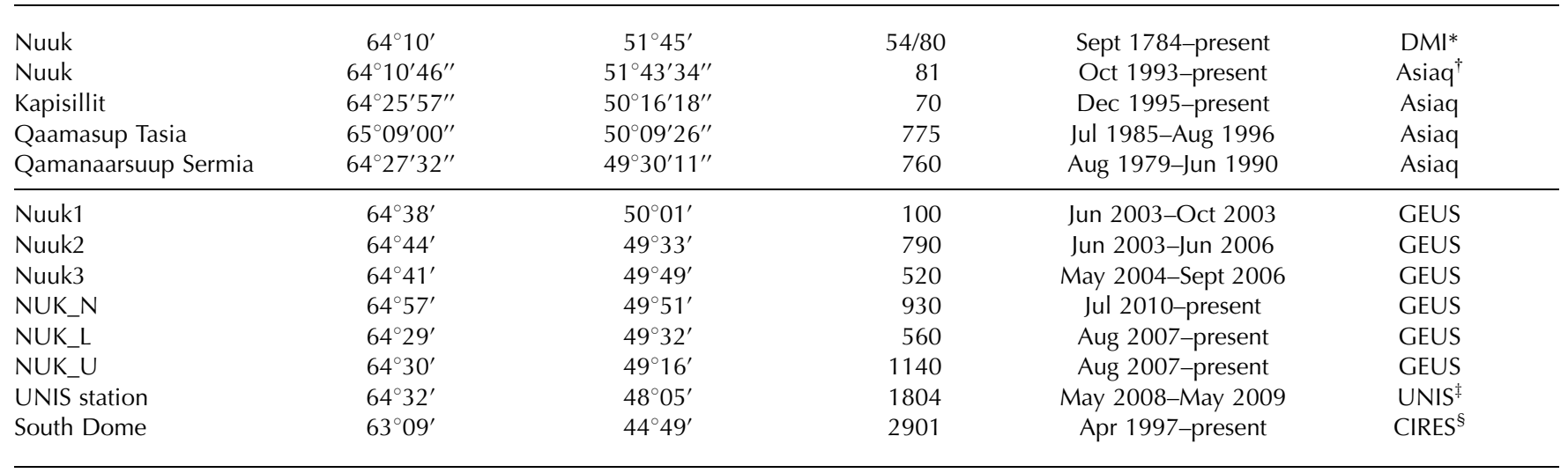

\footnotetext{
*The older (i.e. pre-20th-century) data are from various sources.

†reenland Technical Organization (GTO) before 1993.

*The University Centre in Svalbard.

${ }^{\S}$ Cooperative Institute for Research in Environmental Sciences, Boulder, CO.
} 
RMSE values close to the measurement uncertainties of the radiometers. Summer ice-sheet albedo is overestimated by the RCMs at nearly all sites, which will directly influence melt calculations due to reduced absorption of shortwave radiation. Downward longwave radiation is underestimated by the RCMs by $\sim 10-30 \mathrm{~W} \mathrm{~m}^{-2}$ at all sites, also causing calculated melt to be underestimated.

The selected AWSs on land are equipped with precipitation gauges, allowing for an evaluation of modelled precipitation. The uncertainties in (especially solid) precipitation measurements are large, with known examples of measurement errors of up to $100 \%$ (Allerup and others, 1997). For Greenland, wind-induced undercatch is evaluated to be the greatest error source (Yang and others, 1999). In spite of this, both models calculate (up to a factor of four) lower precipitation values than observed at most sites, though not for the orographically sheltered Kapisillit site, where the models overestimate precipitation. This is illustrative of difficulties in calculating and measuring precipitation, especially in a mountainous region. Comparison with AWS measurements on the ice sheet is provided in Section 3.1. Over the flat accumulation zone of the ice sheet, a detailed comparison between observed and modelled snow accumulation showed good agreement (Ettema and others, 2009).

Finally, RCM runoff from the SS catchment is evaluated using measured discharge at Tasersuaq Lake in Section 3.1, thus comparing area totals rather than local values. The water level in the lake was monitored from 1974 to 1983 and again from 2008 to 2012. Water level is converted into discharge values by a stage-discharge relation, based on manual measurements of discharge over a range of water levels. The scatter in the single stage-discharge measurements yields an uncertainty of $6 \%$ for single values.

\section{RESULTS}

\subsection{Observed versus modelled SMB and runoff}

Most on-ice stations are equipped with sonic height rangers, which record surface height change resulting from accumulation and ablation. The Geological Survey of Denmark and Greenland (GEUS) stations additionally make use of a pressure transducer assembly (Fausto and others, 2012). Figure 3 shows a comparison of measured and modelled surface height change in the lower ablation area (NUK_L) and in the upper accumulation area (South Dome). Modelled surface height change is calculated as snowfall reduced by sublimation, evaporation and melt, bilinearly interpolated to the AWS location. It does not include refreezing, which occurs below the surface. Differences between models and observations are significant. At NUK_L, where 5-7 $\mathrm{m}$ of ice ablates per year, the models underestimate net ablation by $\sim 30-50 \%$, which cannot be explained fully by small-scale variability in ablation as seen from local stake measurements (Braithwaite, 1986). The difference is mainly due to overestimated accumulation and bare-ice albedo. The lack of winter accumulation on the QS outlet below 900 m elevation was reported by Braithwaite (1986) and is likely due to orographic sheltering and snow being blown into surface depressions and crevasses, thus not accumulating underneath the instruments. A similar lack of accumulation was reported for the marginal ice sheet near Kangerlussuaq (Van As and others, 2012). In the accumulation area (South Dome), the surface height increase is

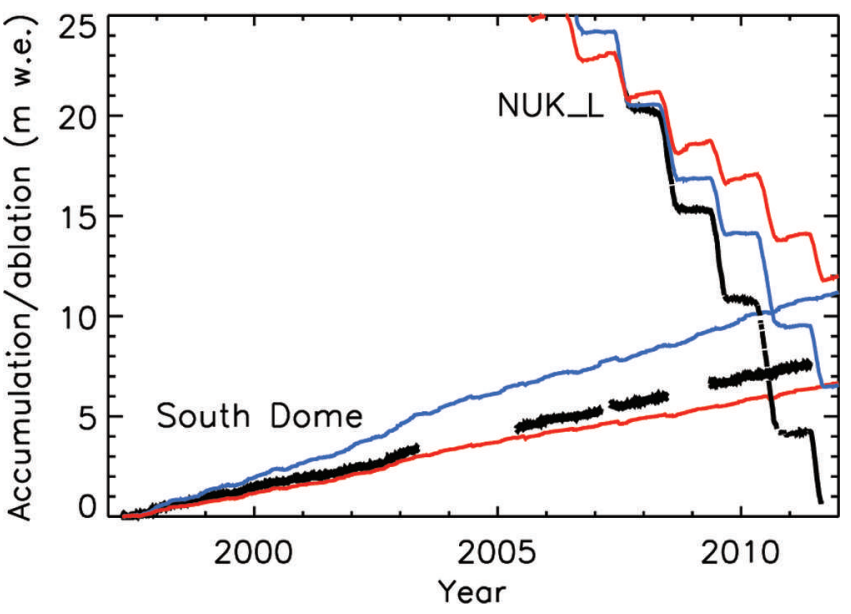

Fig. 3. Cumulative surface height change due to accumulation and ablation at the NUK_L and South Dome on-ice weather stations. Black lines: observations; blue lines: MARv3.2; red lines: RAC$\mathrm{MO} 2$. For conversion of surface height change measurements into w.e. a snow/ice density of $350 / 900 \mathrm{~kg} \mathrm{~m}^{-3}$ is used.

larger in MARv3.2 than in RACMO2 due to differences in snowfall. Depending on the snow density used to convert the measurement into comparable units (here $350 \mathrm{~kg} \mathrm{~m}^{-3}$; Box, 2001), also at this site the mass budget disagrees with measurements by up to $30 \%$.

Model performance improves on the catchment scale; this is illustrated in Figure 4, which compares discharge measurements at the TL river outlet with daily catchment totals for modelled runoff from SS. We applied a 1 week delay and 15 day smoothing to RACMO2 runoff values to represent (in basic form and for plotting purposes only) meltwater routing delays. MARv3.2 calculates a runoff delay following Zuo and Oerlemans (1996). Both models produce realistic runoff quantities and temporal variability therein, although there is evidence to suggest that runoff is underestimated in the high-melt years 2010-12. The agreement with discharge observations is reduced when modelled runoff from the tundra TL catchment, which peaks in spring when snow melts, is also taken into account. Many of the smaller lakes in the TL catchment may not drain into Tasersuaq Lake, their main sinks being evaporation and/or interaction with groundwater. More importantly, the TL measurements do not reveal the runoff used for the $\sim 7 \mathrm{~m}$ water level increase in spring. The nonzero lake discharge values in autumn and winter are similarly the result of lake volume decrease, but could also be due to englacial storage (Rennermalm and others, 2013), or melt- and rainwater from the tundra reaching the lake with delay due to groundwater interaction.

In conclusion, for single locations, errors and uncertainties in RCMs as well as observations can prevent a useful comparison, as seen at the AWS sites. However, integrating the data over the scale of a glacial catchment produces improved agreement between models and observations.

\subsection{Melt, runoff and SMB in the Nuuk region of the ice sheet}

The pronounced annual cycle in Figure 4 is due to melt, which is confined to the warm season. Figure $5 \mathrm{~b}$ illustrates that ice-sheet melt in the Nuuk region occurs chiefly in May-September, peaking at $>10 \mathrm{~km}^{3}$ w.e. in July (1960-2012 

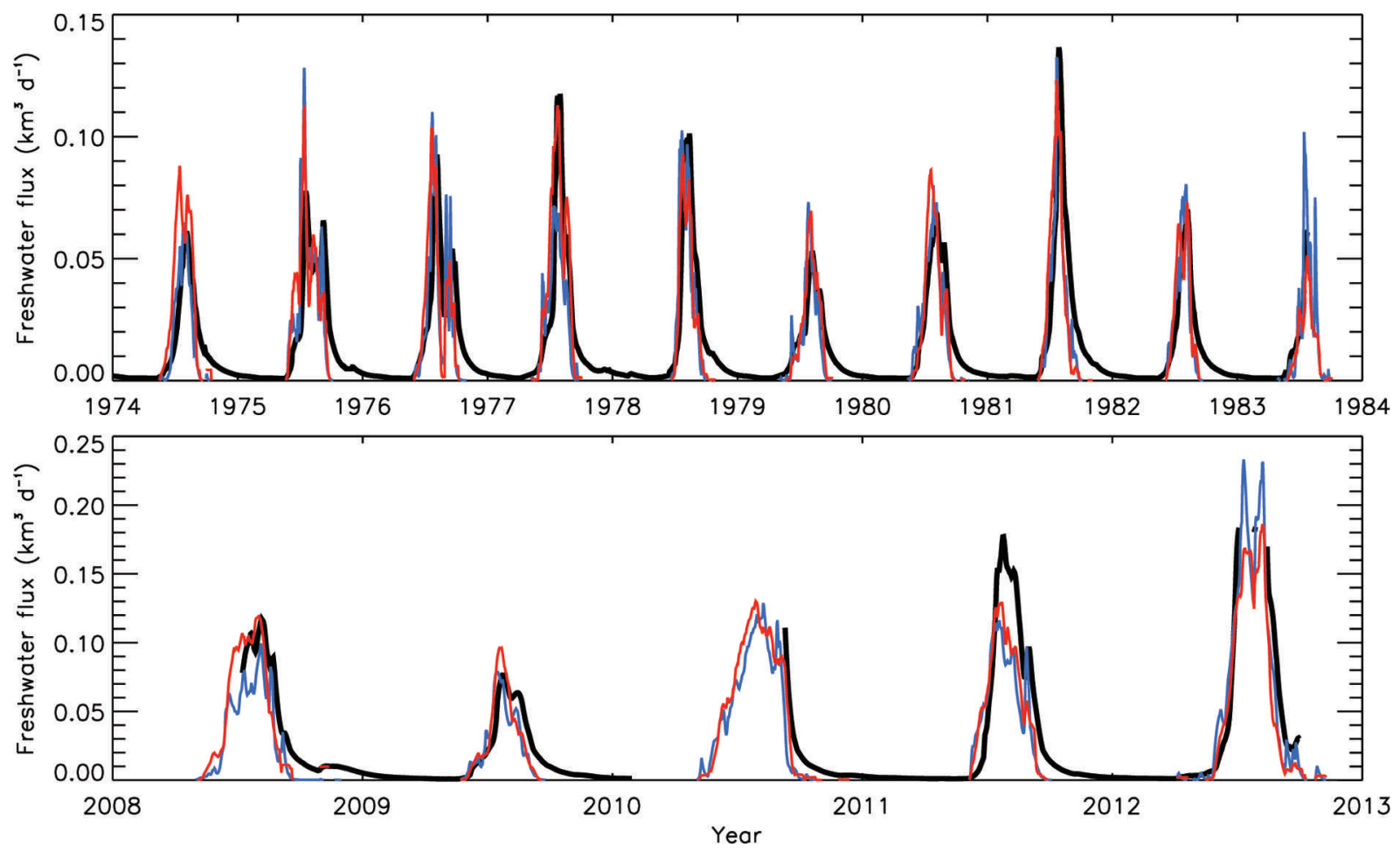

Fig. 4. Observed discharge from Tasersuaq Lake (black), and runoff as calculated by MARv3.2 (blue) and RACMO2 (red) for catchment SS.

average). Since rainfall (Fig. 5a) has the same seasonality, though approximately a factor of ten smaller in magnitude, this is also valid for runoff (Fig. 5d). Runoff equals meltwater and rainwater combined, reduced by what is refrozen in snow and firn (Fig. 5c). According to the two models, in the period 1960-2012, almost half of all liquid water refroze.

The SMB for the region is calculated as snowfallsublimation/evaporation - melt + refrozen mass (equal to precipitation - sublimation/evaporation-runoff). The average SMB is negative in June, July and August (Fig. 5f). Snow accumulates in the higher regions of the catchments throughout the year, peaking slightly in autumn, so melt mostly forces the yearly cycle in SMB. Regionally, sublimation and evaporation contribute little to the SMB (Fig. 5e).

Annual total values for 1960-2012 are illustrated in Figure 6. Surface melt increased from an average of $20-25 \mathrm{~km}^{3} \mathrm{a}^{-1}$ w.e. from 1960 to the mid-1990s to values $50-150 \%$ higher in recent years (Fig. 6b). The melt increase is well documented: 2007 was the strongest melt year on

Table 2. Contributions from catchments to the runoff from the Nuuk ice sheet region, including standard deviation calculated from annual totals

\begin{tabular}{lrr} 
Catchment & MARv3.2 runoff & RACMO2 runoff \\
& \multicolumn{1}{c}{$\%$} & \multicolumn{1}{c}{$\%$} \\
\hline SS & $31.4 \pm 1.4$ & $40.8 \pm 2.4$ \\
KS & $8.3 \pm 0.4$ & $6.8 \pm 0.4$ \\
NS & $18.1 \pm 0.5$ & $15.1 \pm 1.0$ \\
QS & $7.0 \pm 0.5$ & $5.6 \pm 0.4$ \\
AS & $9.2 \pm 0.4$ & $7.0 \pm 0.6$ \\
KNS & $21.9 \pm 1.0$ & $20.5 \pm 1.1$ \\
IL & $4.1 \pm 0.3$ & $4.4 \pm 0.6$
\end{tabular}

record (Tedesco and others, 2008) until 2010 (Tedesco and others, 2011; Van As and others, 2012), which was surpassed by 2012 (Tedesco and others, 2013). In the Nuuk region, $>50 \mathrm{~km}^{3}$ of meltwater was generated in 2012 .

The amount of melt- and rainwater that was calculated to refreeze remained stable at $10-15 \mathrm{~km}^{3}$ w.e. throughout the period (with 2012 as an outlier), causing runoff to increase relatively more than melt (Fig. $6 \mathrm{~d}$ ). Although rainfall also increased during the 53 year period, it contributes $<5 \mathrm{~km}^{3}$ w.e. $\mathrm{a}^{-1}$.

The SS catchment produces most runoff in the Nuuk region (Table 2), with a mean contribution of $31 \%$ or $41 \%$, depending on the model used. Whereas the models calculate very similar SMB components in the SS catchment (e.g. average melt within 5\% and runoff within $2 \%$ ), in most other catchments MARv3.2 gives higher melt (12\%) and less refrozen mass $(16 \%)$ than RACMO2. This is on average accompanied by (and presumably also caused by) lower solid precipitation values $(17 \%)$. The models calculate that there is no trend in the relative runoff contributions from the catchments, as indicated by the small standard deviations in Table 2. This suggests that runoff from the catchments reacts similarly to climate forcing, in spite of the different catchment shapes. More importantly, this means that it suffices to monitor the runoff from one catchment (as at Tasersuaq Lake) to be able to estimate the annual freshwater discharge into Godthåbsfjord from all catchments. However, the models do not agree on the relative contributions from the catchments (Table 2), and this requires further study.

When calculating the hydrological contribution of KNS to Godthåbsfjord a complicating factor is that the ice-sheet region $\mathrm{IL}$, which drains water into the ice-dammed Isvand Lake, is dynamically part of KNS, but hydrologically only partly so. After the formation of the lake in the 18th century, the lake water spilled over into Austmannadalen and flowed into Ameralik Fjord, which has no direct connection to 

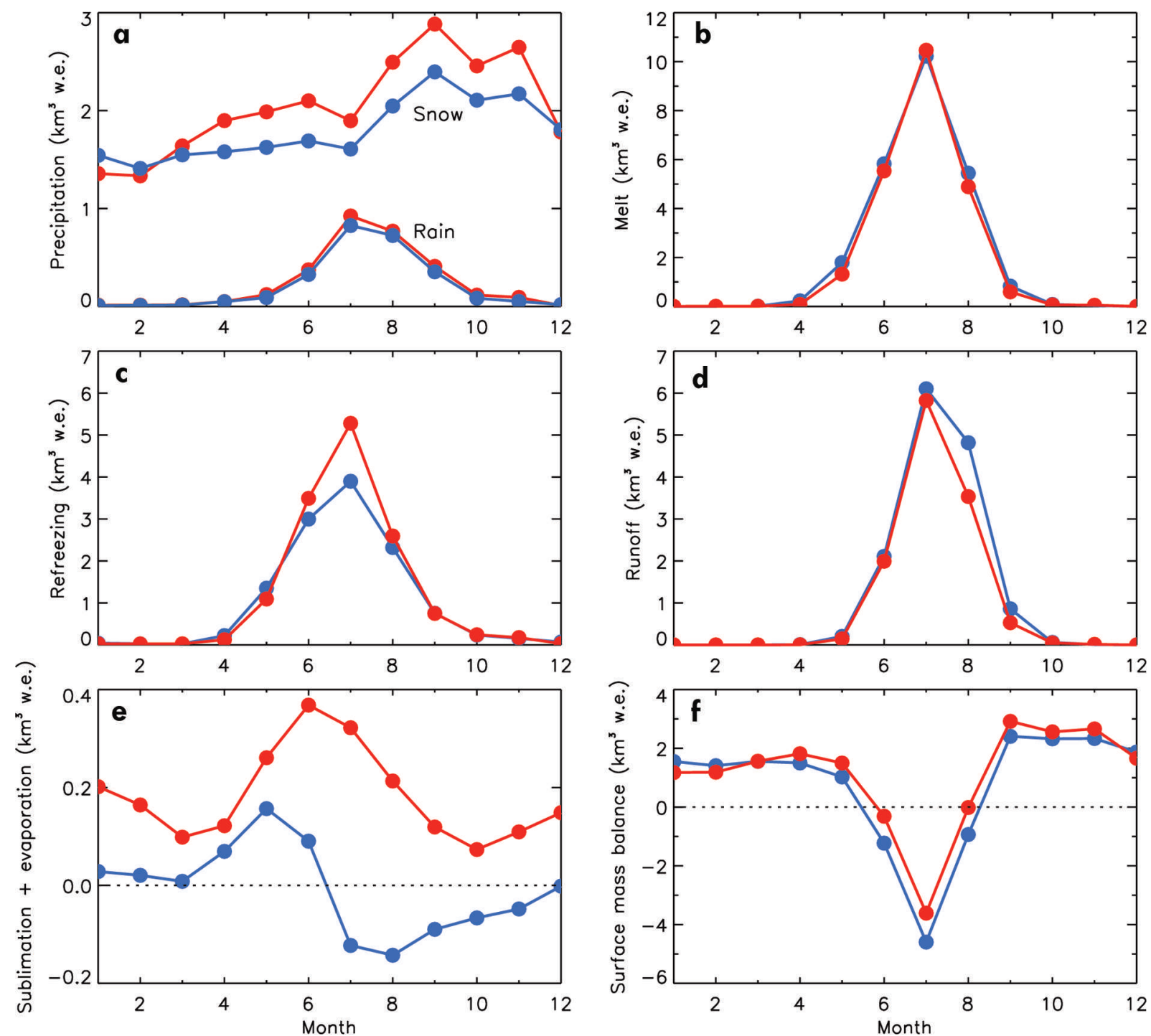

Fig. 5. Mean annual cycles of snowfall and rainfall (a), melt (b), refreezing (c), runoff (d), evaporation and sublimation (e) and SMB (f) calculated by MARv3.2 (blue) and RACMO2 (red) for the Nuuk region of the ice sheet for 1960-2012.

Godthåbsfjord. From 2004 onwards, the lake exhibited sudden drainages through the KNS englacial conduit system, until in recent years it lost hydrological connection to Ameralik Fjord altogether. These changes in the lake's hydrological pathways are related to thinning of KNS (Weidick and Citterio, 2011). For the hydrology of Godthåbsfjord, this implies that in recent years KNS runoff increased, receiving a larger share of IL runoff, which is a model average of $20 \%$ of the KNS value for 1960-2012. As with all ice-dammed (or supraglacial) lakes in the region, the timing of freshwater release due to episodic drainages cannot be modelled with accuracy and is therefore not discussed here.

Compared with the runoff from the ice sheet, the three mostly ice-free catchments of TL, GFI and GFO produce small but non-negligible freshwater fluxes. The catchments receive mean annual precipitation quantities of 2.2, 2.0 and $1.8 \mathrm{~km}^{3}$ for $1960-2012$ according to MARv3.2, and 2.6, 3.4 and $3.3 \mathrm{~km}^{3}$ according to RACMO2. In low-melt years the modelled precipitation in the ice-free catchments exceeds the total runoff from the ice sheet. However, as discussed with Figure 4, it is not known how much of this makes it to the fjord, and when.
With snowfall on the ice sheet in the region unchanging throughout the period 1960-2012 (Fig. 6a), and mass loss/ gain due to sublimation and evaporation being an order of magnitude smaller than the other SMB components, the changes in regional SMB during the study period are the result of melt. Throughout most of the period, SMB was positive and trendless at $10-15 \mathrm{~km}^{3}$ w.e. $\mathrm{a}^{-1}$ on average, with precipitation causing most of the interannual variability. The trend changed around 2000 when melt started increasing, causing SMB to decrease. This melt increase is a consequence of an increase in negative phases of the NAO, favouring warmer and drier summers over the ice sheet (Fettweis and others, 2013). Since the end of the 1990s, the occurrence of anticyclones centred over the ice sheet has doubled, which induces more frequent southerly warm air advection along the western Greenland coast. In recent extreme melt years this led to a negative modelled SMB. In the warm year 2010, the average SMB for the region was calculated to be $-6.7 \mathrm{~km}^{3}$ w.e., with models in agreement. In 2012, for which an average SMB of $-0.9 \mathrm{~km}^{3}$ w.e. is calculated, the model values differ by nearly $20 \mathrm{~km}^{3}$ w.e. due to differences in solid precipitation and refreezing. In the long-term perspective given in Figure $6 \mathrm{c}$ it is likely that 

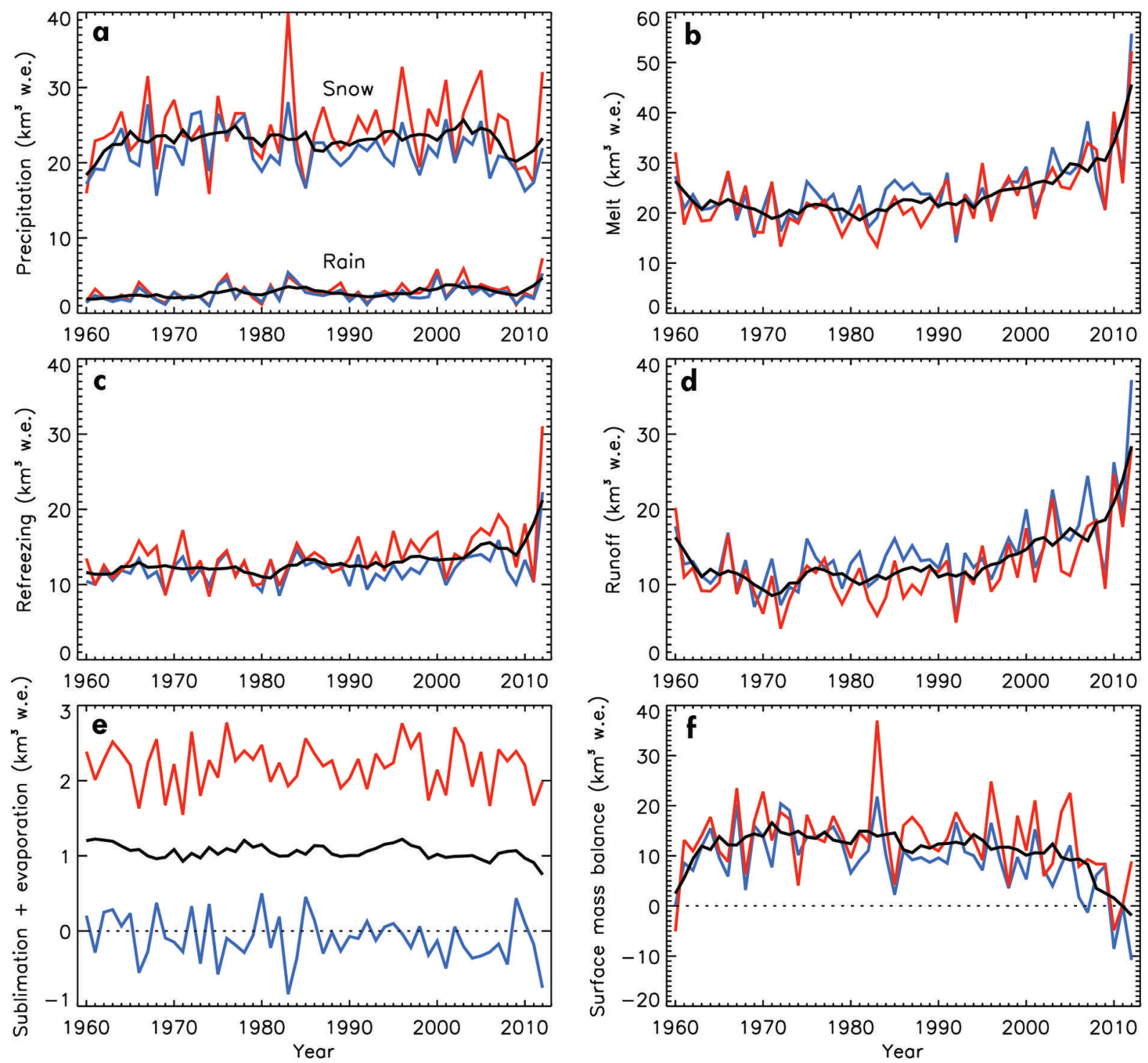

Fig. 6. Same as Figure 5, but annual totals. The solid black line illustrates the 5 year running mean for both models combined.

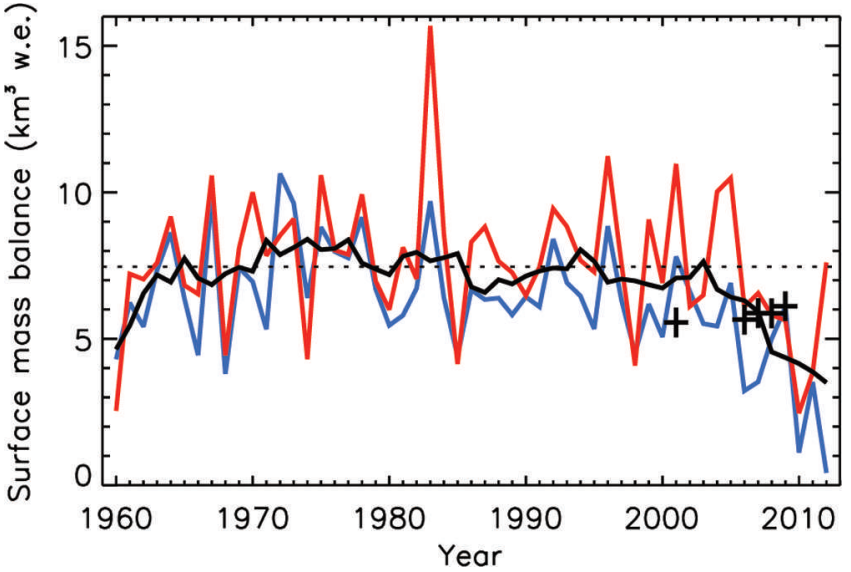

Fig. 7. SMB for the KNS + IL catchment as calculated by MARv3.2 (blue) and RACMO2 (red). Frontal ablation (calving + melt) estimates for KNS are indicated by crosses (+), with their vertical extent indicating the uncertainty. These wintertime RADARSAT-derived dynamic fluxes were increased by $10 \%$ to better represent the annual mean flux (Ahlstrøm and others, 2013). The solid black line indicates the 5 year running mean, and the dotted line the 1961-90 average, for both models combined. model-average refreezing is overestimated in 2012, and that the annual SMB is more similar to that of 2010.

The three marine-terminating glaciers NS, AS and KNS contributed to additional regional mass loss due to frontal ablation (calving + melt). Accurate frontal ablation is known only for KNS, as this is the only glacier in this region for which there is some knowledge of bed topography (Gogineni, 2012). Five values, based on remotely sensed wintertime surface velocity maps (Joughin and others, 2010), increased by $10 \%$ to account for spring/summer speed-up (Ahlstrøm and others, 2013) are plotted with the SMB values for KNS in Figure 7. The SMB trend is similar to that for the entire ice-sheet region (Fig. $6 \mathrm{f}$ ), since KNS makes up $42 \%$ of the ice-covered region, but annual values are positive throughout. Taking into account the frontal ablation of KNS, the data imply that KNS was gaining mass until about 2007. Rignot and Kanagaratnam (2006) reported that KNS accelerated by $6 \%$ from 1996 to 2000 and by another $27 \%$ by 2005 . This makes it unlikely that frontal ablation could have balanced the positive SMB before 1996 (Fig. 7), also implying a mass gain. Since the outlet glaciers in the region are unlikely to have thickened or lengthened during this period (Weidick and others, 2012), this means that either the 
ice sheet was gaining mass in the accumulation area, or that the SMB is overestimated by the RCMs. If the former is true, the model average mass balance for KNS was $\sim-2$ to $-4 \mathrm{~km}^{3}$ w.e. $\mathrm{a}^{-1}$ for 2010-12. However, the model evaluation in this study shows that melt is underestimated, and that precipitation/accumulation may be overestimated, which would justify a downward adjustment of the SMB values. If we assume more realistically that KNS was at balance during 1961-90, a commonly used climatic reference period (dotted line denoting the SMB equilibrium level in Fig. 7), the glacier lost $5-6 \mathrm{~km}^{3}$ w.e. in 2010 , the equivalent of a mean surface lowering of $\sim 0.3 \mathrm{~m}$ w.e.

Similarly, it is improbable that the frontal ablation for NS, AS and KNS combined exceeded $10 \mathrm{~km}^{3}$ w.e. to balance out the positive regional SMB (Fig. 6) during any year over the study period, since KNS is by far the most productive of the three $\left(\sim 6 \mathrm{~km}^{3}\right.$ w.e. $\mathrm{a}^{-1}$; Fig. 7). The 1961-90 mean SMB of $+13 \mathrm{~km}^{3}$ w.e. $\mathrm{a}^{-1}$ would have yielded a mean ice-sheet thickening of $>0.1 \mathrm{mw}$.e. $\mathrm{a}^{-1}$, which was not observed (Krabill and others, 2000). This promotes a downward SMB adjustment of $4-6 \mathrm{~km}^{3}$ w.e. $\mathrm{a}^{-1}$ to match frontal ablation. If we again assume that the ice-sheet region was in balance for 1961-90, the Nuuk sector of the ice sheet lost a model average of $20 \mathrm{~km}^{3}$ w.e. in 2010 . This value is considered a lower estimate, since frontal ablation is likely to have increased rather than been stable since the reference period (Rignot and Kanagaratnam, 2006; Joughin and others, 2010).

\section{CONCLUSIONS}

Comparison of interpolated RCM data with point AWS measurements in the ablation zone shows disagreement by $\sim 30-50 \%$, mainly caused by an overestimated surface albedo in summer and underestimated downward longwave radiation values. The agreement with observations improves when mass fluxes are integrated over glacier catchments, as indicated by a comparison with proglacial lake discharge with SS catchment runoff.

Based on the output of the RCMs, we find that surface melt in the Nuuk region of the ice sheet has doubled in recent years compared with previous decades, and that runoff increased by a larger percentage due to a reduction in the freshwater fraction that refroze. The increase of modelled runoff is in line with the observed increase in ablation since the 1980s; Braithwaite (1986) reported annual ablation values of 3-4 mw.e. for the location where NUK_L measurements indicate ablation of $5-7 \mathrm{~m} \mathrm{a}^{-1}$ since 2007 (Fig. 3). Since the share in runoff from the individual catchments remains constant under variable climate conditions during the study period, the monitoring of runoff from the SS catchment appears representative for the freshwater flux into the whole of Godthåbsfjord.

In this study we highlighted results from KNS, the glacier with the largest calving flux on the west coast south of Jakobshavn Isbræ, because we have substantiated estimates of its ice-dynamic discharge, providing us with the possibility of estimating its total mass budget. The lower regions of KNS were thinning and retreating in the decades before 2000, along with AS and QS (Taurisano and others, 2003; Weidick and Citterio, 2011). From this we determine that at best we can assume mass equilibrium for reference period 1961-90 (a common assumption for the whole ice sheet), given that no large thickening of the upper ice-sheet region occurred. A downward SMB adjustment to match recent frontal ablation values implies that KNS lost mass in recent years, peaking at $5-6 \mathrm{~km}^{3}$ w.e. in 2010 . We argue that this adjustment is justified because the comparison with measurements reveals that the models generally underestimate ablation and overestimate precipitation/accumulation.

The average $\mathrm{SMB}$ for the entire region of the ice sheet is $+11 \mathrm{~km}^{3}$ w.e. $\mathrm{a}^{-1}$ for 1960-2012. Taking into account a frontal ablation estimate of the three marine-terminating glaciers of $7-10 \mathrm{~km}^{3}$ w.e. $\mathrm{a}^{-1}$ in recent years, this implies a mean thickening exceeding $0.04 \mathrm{mw}$.e. $\mathrm{a}^{-1}$ for the entire region, which was not observed. More probable SMB values are obtained by a downward adjustment; if we again assume that the ice-sheet region was in near-balance in the reference period (1961-90), an imbalance of $20 \mathrm{~km}^{3}$ w.e. is found for the high-melt year 2010.

The high melt in Greenland in recent years is not purely a result of anthropogenic climate change, but also of largescale atmospheric circulation patterns influenced by, for example, the NAO (Van Angelen and others, 2012; Fettweis and others, 2013). However, strong melt conditions could prevail in a warming climate. If 2010 conditions were to become the standard, a $5 \mathrm{~mm}$ sea-level rise is to be expected by 2100 from this relatively small region of the ice sheet $(2.6 \%)$, which could be enhanced by processes such as the melt-albedo feedback and increased frontal ablation.

\section{ACKNOWLEDGEMENTS}

We thank the Greenland Climate Research Centre in Nuuk for financial and logistical support (GCRC project No. 6509). Additional funding was received from the FreshLink project and the Programme for Monitoring the Greenland Ice Sheet (PROMICE). The use of Tasersuaq Lake discharge data since summer 2011 was kindly permitted by London Mining. This is a PROMICE publication.

\section{REFERENCES}

Ahlstrøm AP and 13 others (2013) Seasonal velocities of eight major marine-terminating outlet glaciers of the Greenland ice sheet from continuous in situ GPS instruments. Earth Syst. Sci. Data, 5(2), 277-287 (doi: 10.5194/essd-5-277-2013)

Allerup P, Madsen H and Vejen F (1997) A comprehensive model for correcting point precipitation. Nord. Hydrol., 28(1), 1-20 (doi: 10.2166/nh.1997.001)

Andersen ML and 14 others (2010) Spatial and temporal melt variability at Helheim Glacier, East Greenland, and its effect on ice dynamics. J. Geophys. Res., 115(F4), F04041 (doi: 10.1029/ 2010JF001760)

Barletta VR, Sørensen LS and Forsberg R (2013) Scatter of mass changes estimates at basin scale for Greenland and Antarctica. Cryosphere, 7(5), 1411-1432 (doi: 10.5194/tc-7-1411-2013)

Box JE (2001) Surface water vapor exchanges on the Greenland Ice Sheet derived from automated weather station data. (PhD thesis, University of Colorado)

Box JE (2002) Survey of Greenland instrumental temperature records: 1873-2001. Int. J. Climatol., 22(15), 1829-1847 (doi: 10.1002/joc.852)

Box JE, Fettweis X, Stroeve JC, Tedesco M, Hall DK and Steffen K (2012) Greenland ice sheet albedo feedback: thermodynamics and atmospheric drivers. Cryosphere, 6(4), 821-839 (doi: 10.5194/tc-6-821-2012)

Braithwaite RJ (1986) Assessment of mass-balance variations within a sparse stake network, Qamanârssûp sermia, West Greenland. J. Glaciol., 32(110), 50-53 
Dee DP and 35 others (2011) The ERA-Interim reanalysis: configuration and performance of the data assimilation system. Q. J. R. Meteorol. Soc., 137(656), 553-597 (doi: 10.1002/qj.828)

Ettema J and 6 others (2009) Higher surface mass balance of the Greenland ice sheet revealed by high-resolution climate modelling. Geophys. Res. Lett., 36(12), L12501 (doi: 10.1029/ 2009GL038110)

Fausto RS, Van As D, Ahlstrøm AP and Citterio M (2012) Assessing the accuracy of Greenland ice sheet ice ablation measurements by pressure transducer. J. Glaciol., 58(212), 1144-1150 (doi: 10.3189/2012JoG12J075)

Fettweis X, Tedesco M, Van den Broeke M and Ettema J (2011) Melting trends over the Greenland ice sheet (1958-2009) from spaceborne microwave data and regional climate models. Cryosphere, 5(2), 359-375 (doi: 10.5194/tc-5-359-2011)

Fettweis X, Hanna E, Lang C, Belleflamme A, Erpicum M and Gallée H (2013) Brief communication: 'Important role of the mid-tropospheric atmospheric circulation in the recent surface melt increase over the Greenland ice sheet'. Cryosphere, 7(1), 241-248 (doi: 10.5194/tc-7-241-2013)

Gogineni P (2012) CReSIS radar depth sounder data. Center for Remote Sensing of Ice Sheets, Lawrence, KS https://data.cresis.ku.edu

Hanna E and 6 others (2013) The influence of North Atlantic atmospheric and oceanic forcing effects on 1900-2010 Greenland summer climate and ice melt/runoff. Int. J. Climatol., 33(4), 862-880 (doi: 10.1002/joc.3475)

Hvidegaard SM, Sørensen LS and Forsberg R (2012) ASTER GDEM validation using LiDAR data over coastal regions of Greenland. Remote Sens. Lett., 3(1), 85-91 (doi: 10.1080/01431161.2010. 527389)

Joughin I, Smith BE, Howat IM, Scambos T and Moon T (2010) Greenland flow variability from ice-sheet-wide velocity mapping. J. Glaciol., 56(197), 415-430 (doi: 10.3189/ 002214310792447734)

Krabill WB and 9 others (2000) Greenland ice sheet: high-elevation balance and peripheral thinning. Science, 289(5478), 428-430 (doi: 10.1126/science.289.5478.428)

Mortensen J and 6 others (2013) On the seasonal freshwater stratification in the proximity of fast-flowing tidewater outlet glaciers in a sub-Arctic sill fjord. J. Geophys. Res., 118(3), 1382-1395 (doi: 10.1002/jgrc.20134)

Nghiem SV and 8 others (2012) The extreme melt across the Greenland ice sheet in 2012. Geophys. Res. Lett., 39(20), L20502 (doi: 10.1029/2012GL053611)

Rae JGL and 14 others (2012) Greenland ice sheet surface mass balance: evaluating simulations and making projections with regional climate models. Cryosphere, 6(6), 1275-1294 (doi: 10.5194/tc-6-1275-2012)

Reijmer CH, Van den Broeke MR, Fettweis X, Ettema J and Stap LB (2012) Refreezing on the Greenland ice sheet: a comparison of parameterizations. Cryosphere, 6(4), 743-762 (doi: 10.5194/tc6-743-2012)

Rennermalm AK and 7 others (2013) Evidence of meltwater retention within the Greenland ice sheet. Cryosphere, 7(5), 1433-1445 (doi: 10.5194/tc-7-1433-2013)

Rignot E and Kanagaratnam P (2006) Changes in the velocity structure of the Greenland Ice Sheet. Science, 311(5673), 986-990 (doi: 10.1126/science.1121381)
Rignot E, Velicogna I, Van den Broeke MR, Monaghan A and Lenaerts J (2011) Acceleration of the contribution of the Greenland and Antarctic ice sheets to sea level rise. Geophys. Res. Lett., 38(5), L05503 (doi: 10.1029/2011GL046583)

Sasgen I and 8 others (2012) Timing and origin of recent regional ice-mass loss in Greenland. Earth Planet. Sci. Lett., 333-334, 293-303 (doi: 10.1016/j.epsl.2012.03.033)

Steffen K, Box J and Abdalati W (1996) Greenland climate network: GC-net. CRREL Spec. Rep. 96-27, 98-103

Taurisano A, Bøggild CE, Schjøth F and Jepsen H (2003) Elevation change on the Greenland Ice Sheet at Qamanarssup Sermia, West Greenland. Polar Geogr., 27(1), 59-68 (doi: 10.1080/789610222)

Tedesco M, Serreze M and Fettweis X (2008) Diagnosing the extreme surface melt event over southwestern Greenland in 2007. Cryosphere, 2(2), 159-166 (doi: 10.5194/tc-2-159-2008)

Tedesco M and 7 others (2011) The role of albedo and accumulation in the 2010 melting record in Greenland. Environ. Res. Lett., 6, 014005 (doi: 10.1088/17489326/6/1/014005)

Tedesco M and 6 others (2013) Evidence and analysis of 2012 Greenland records from spaceborne observations, a regional climate model and reanalysis data. Cryosphere, 7(2), 615-630 (doi: 10.5194/tc-7-615-2013)

Van Angelen JH and 7 others (2012) Sensitivity of Greenland Ice Sheet surface mass balance to surface albedo parameterization: a study with a regional climate model. Cryosphere, 6(5), 1175-1186 (doi: 10.5194/tc-6-1175-2012)

Van As D, Hubbard AL, Hasholt B, Mikkelsen AB, Van den Broeke MR and Fausto RS (2012) Large surface meltwater discharge from the Kangerlussuaq sector of the Greenland ice sheet during the record warm year 2010 explained by detailed energy balance observations. Cryosphere, 6(1), 199-209 (doi: 10.5194/ tc-6-199-2012)

Van As D and 15 others (2013) Darkening of the Greenland ice sheet due to the melt-albedo feedback observed at PROMICE weather stations. Geol. Surv. Den. Greenl. Bull., 28, 69-72

Van den Broeke $M$ and 8 others (2009) Partitioning recent Greenland mass loss. Science, 326(5955), 984-986 (doi: 10.1126/science.1178176)

Van den Broeke MR, Smeets CJPP and Van de Wal RSW (2011) The seasonal cycle and interannual variability of surface energy balance and melt in the ablation zone of the west Greenland ice sheet. Cryosphere, 5(2), 377-390 (doi: 10.5194/tc-5-377-2011)

Vinther BM, Andersen KK, Jones PD, Briffa KR and Cappelen J (2006) Extending Greenland temperature records into the late eighteenth century. J. Geophys. Res., 111(D11), D11105 (doi: 10.1029/2005JD006810)

Weidick A and Citterio M (2011) Correspondence. The ice-dammed lake Isvand, West Greenland, has lost its water. J. Glaciol., 57(201), 186-188 (doi: 10.3189/002214311795306600)

Weidick A, Bennike O, Citterio M and Nørgaard-Pedersen N (2012) Neoglacial and historical glacier changes around Kangersuneq Fjord in southern West Greenland. Geol. Surv. Den. Greenl. Bull., 27

Yang DQ, Ishia S, Goodison BE and Gunther T (1999) Bias correction of daily precipitation measurements for Greenland. J. Geophys. Res., 104(D6), 6171-6181 (doi: 10.1029/1998JD200110)

Zuo Z and Oerlemans J (1996) Modelling albedo and specific balance of the Greenland ice sheet: calculations for the Søndre Strømfjord transect. J. Glaciol., 42(141), 305-317 